\title{
Understanding artefacts related to human aspects: The case of information technology and systems
}

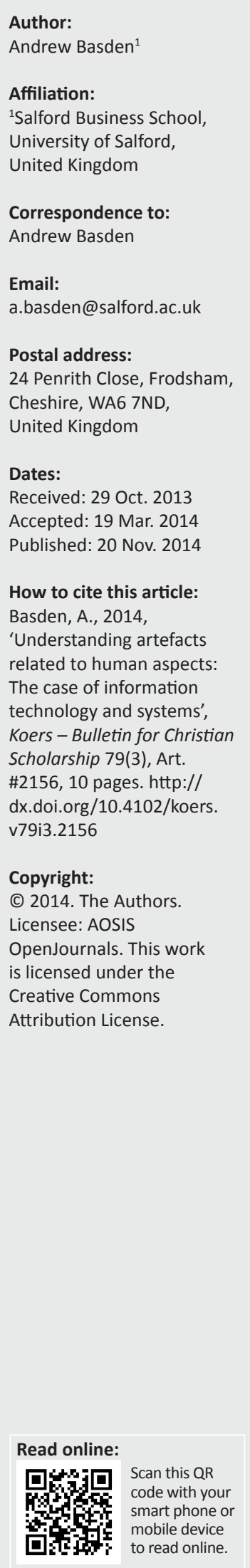

This article has two aims. One is to critique and expand Stafleu's ideas about artefacts. The other, which may be seen as a demonstration of this expansion, is an outline of a rich view of the type of artefact that is information and communication technology (ICT) and its use in human life as information systems (IS). ICT is a kind of artefact that is more complex than those covered by Stafleu's idea, and it has been considered in at least five ways: the artificial intelligence question of what is the computer, the computer question of the generation of software libraries, the question of how to develop good information systems, the question of benefits and harm when using ICT, and the question of impact that ICT and society have on each other. An important sixth question is about the varied nature of research into all the above, which goes beyond Stafleu's idea of scientific research to include design, interpretive and critical research. For each of these questions, a brief outline of mainstream approaches is followed by an approach based on various parts of Dooyeweerd's philosophy. The final two sections consists of a discussion of the assistance that Dooyeweerdian philosophy can offer in these six areas and, in turn, how research in these areas might contribute to Dooyeweerdian philosophy.

Die verstaan van artefakte verwant aan menslike aspekte: Die geval van inligtingstegnologie en - sisteme. Hierdie artikel het twee doelwitte. Die eerste doelwit is om Stafleu se idees oor artefakte te kritiseer en uit te brei. Die tweede doelwit, wat as 'n demonstrasie van hierdie uitbreiding beskou kan word, is om 'n uiteensetting van inligtingsen kommunikasietegnologie (IKT) as 'n tipe artefak te bied, sowel as om na die gebruik daarvan in die menslike lewe, as inligtingsisteme (IS), te verwys. IKT is 'n tipe artefak wat meer kompleks is as daardie artefakte wat deur Stafleu se idee gedek word. IKT is al op minstens vyf maniere benader: die kunsmatige intelligensie-kwessie oor wat die rekenaar is, die rekenaarkwessie oor die generering van sagteware-biblioteke, hoe goeie inligtingstelsels ontwikkel kan word, die vraag oor die voordele en skade in die gebruik van IKT, en die vraag oor die wedersydse impak van IKT en die samelewing. 'n Belangrike sesde vraag handel oor die uiteenlopende aard van die navorsing soos dit in bogenoemde na vore kom, wat verder gaan as Stafleu se idee van wetenskaplike navorsing om ontwerp, interpretatiewe en kritiese navorsing in te sluit. ' $n$ Kort oorsig van die hoofstroom-benaderings word vir elk van hierdie ses kwessies uiteengesit, gevolg deur ' $n$ benadering wat gebaseer is op aspekte van Dooyeweerd se filosofie. In die laaste twee afdelings word aangedui hoe Dooyeweerd se filosofie van waarde kan wees in hierdie ses areas, asook hoe navorsing in hierdie areas op hulle beurt 'n bydrae kan lewer tot Dooyeweerdiaanse filosofie.

\section{Introduction}

Stafleu's (2014) article clearly outlines a systematic account of what he believes about artefacts and technology, remarking that 'both Dooyeweerd and Strauss ... almost ignor[e] technology'. He takes some time clarifying ways in which he agrees and disagrees with Dooyeweerd and Strauss in their views of aspects, things and theoretical thought. Some of his clarifications are very useful, forming a good basis for further discussion about artefacts.

Stafleu's view is that both artefacts and technology are made possible and meaningful by human functioning in the aspect whose kernel is formative power, and the main aim of his discourse seems to be to set out his understanding of different kinds of artefact. (Though Dooyeweerd calls this the historical aspect, and Stafleu calls it the technical aspect, it is useful to express its meaning as richer than these with the term 'formative aspect', which will be used here.)

Artefacts are entities in which formative power is key, but there are many different kinds of artefact, and these may be differentiated, suggests Stafleu, by reference to the aspect onto which the formative power or technical activity is projected. This is a very useful insight, but unfortunately Stafleu limits it and introduces some confusion. 
Stafleu's discussion is restricted to artefacts where formative power is projected onto one of the six pre-human aspects. This restriction might make it dangerous to generalise because the human aspects open up many philosophical and practical possibilities beyond these. So my response will consider a kind of artefact and technology directed to one of the human aspects, the lingual: the computer and information and communication technology (ICT). It is useful to consider ICT because it is that technology which is so significantly changing our lives today for both good and ill.

This article may be treated as more than a response to Stafleu (2014) in that it outlines how Dooyeweerdian philosophy can be exceedingly fruitful in studying ICT, and even how that study can inform Dooyeweerdian philosophy itself.

A note on terminology: although Stafleu replaces Dooyeweerd's term 'aspect' with 'relation frame', I revert to Dooyeweerd's usage, as being more comprehensive in that it expresses things other than relations, and as more faithful to the importance of meaning and normativity, which are important in ICT.

\section{Stafleu's view of artefacts}

Stafleu (2014) locates artefacts primarily in the formative aspect and secondarily in one of the six pre-human aspects to differentiate six kinds of artefact. For each he illustrates activities, concrete technical artefacts and disciplines:

- Quantitative examples: counting, calculators, mathematics.

- Spatial examples: measurement, instruments, geometry.

- Kinematic examples: travelling, railways.

- Physical examples: stone-working, tools, chemistry.

- Biotic examples: cultivation, ploughs, agriculture.

- Psychic examples: cycling, bicycles.

For each of these, he proposes corresponding processes, techniques, artefact types and technologies, and briefly charts their historical development. Each illustrates Dooyeweerd's suggestion that progress or history is constituted in 'opening

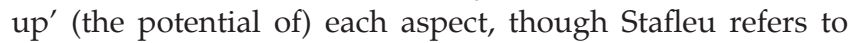
this idea only later.

He calls this application of technology 'projection' of the formative aspect onto earlier ones. He seems to be referring to the application of technology to serve or assist the functioning in another aspect. This idea of 'application' of one aspect for the sake of another is important, but it is not adequately developed in Dooyeweerd.

He also claims it can replace Dooyeweerd's notion of retrocipation. This is confusing, because retrocipation, as I understand it, involves either foundational dependency or an analogy, whereas the 'application' or 'serving' relationship is distinct from both of these (Basden 2008a:72). Stafleu seems to conflate the notion of founding aspect with that of application, especially in discussing projection to the physical and biotic aspects. In the rest of this article I will take projection to refer to the application rather than foundational dependency.

Unfortunately, Stafleu (2014) restricts his discussion to the pre-human aspects. It is curious that he does this, and does not consider technical activities and artefacts where formative functioning is projected onto (serves) the later aspects. After all, did not Dooyeweerd emphasise that things function in all aspects? Restriction to the pre-human aspects means that many issues of normativity in the creation and use of artefacts are likely to be ignored, and that kinds of complexity found in later aspects are not addressed. That later aspects open up new meanings and laws, only dimly echoed in earlier aspects, makes it questionable how far one can generalise from Stafleu's account of projection to earlier aspects.

The computer is an artefact in which our formative functioning is projected onto the lingual aspect. Programs are written rather than built (though some building serves the writing process). The associated technology is called information (and communication) technology (IT or ICT) or information systems (IS) when in use. In this article, 'computer' refers not only to mainframes, desktops and laptops, but also to mobile devices and embedded devices, such as hospital monitoring equipment.

\section{The lingual artefact that is the computer}

Computers exhibit a kind of complexity that Stafleu does not discuss: that of the programmable device, so flexible that it can be employed for almost anything we wish. However, to understand this, we must recognise that the computer presents itself in several different guises. The first is the computer before being programmed. The second is the computer with operating system and general-purpose software libraries. The third is the developed application for use in the world, such as Twitter or health systems. The fourth recognises the importance of the user. The fifth sees the artefact as a global phenomenon. The sixth concerns research that investigates any or all of these.

So, in discussing the nature of this multiple artefact, we will cover the following:

- The nature of computers, programs and the Internet.

- Software libraries, computer languages and HCI: the realisation of lingual possibilities in ICT.

- The development of information systems (IS) for use in the world.

- Actual usage of ICT in its diverse normativity.

- ICT in the world and society.

- Research appropriate to ICT and IS.

For each, a brief history of development will be given, followed by a proposal for understanding the issues of each based on Dooyeweerd's philosophy. Our discussion is necessarily a summary; fuller discussion of each of these can be found in Basden (2008a). 
I believe the qualifying aspect of the computer is the lingual rather than the formative (which qualifies most other technology). This cannot be proven, but in the discussion below several pointers are given as to why it is appropriate.

\section{The nature of computers, programs and the Internet}

Can a computer be like a human being? This 'artificial intelligence' (AI) question has been debated for more than 50 years. The debates have been dialectical conflicts, and three kinds of ground for debate can be discerned:

- Computers are material, mind is mental; can 'mind' emerge from 'brain'?

- Computer causality is physical, human causality is biological.

- Computers work by deterministic laws whereas humans are free.

These are almost direct expressions of the three dualistic ground-motives that Dooyeweerd identified: matterform, nature-supernature (lower and higher levels of existence), nature-freedom. Basden (2008a) suggests that this can explain the non-resolution of the debates, and that a debate grounded in the biblical ground-motive of creation, fall, redemption might bring fruitful resolution, as follows.

The three questions compare computers to the human self, but Dooyeweerd claims that theoretical reflection on the human self is impossible, so what computers must be compared to is human functioning in the aspects. Dooyeweerd's notion of subject and object is helpful, which Stafleu (2014) explains as follows:

With respect to a given law, something is called a subject if it directly or actively satisfies that law. It is an object if it indirectly or passively satisfies that law. (p. 1)

Computers, therefore, may be treated as either subject or object. We can ask the AI question from the perspective of either object- or subject-functioning, and can do so in each aspect (see Table 1).

In this way, a Dooyeweerdian answer to the AI question might be both 'Yes' and 'No', depending on whether we answer from the point of view of subject or meaningful object. The debate, then, is no longer a conflict but can move on to a more fruitful discussion of various aspects in which the computer functions.

The most important element of a computer is that it is programmed. What are computer programs? The conventional answer is 'sequences of instructions', but what are 'instructions'? Since Dooyeweerd ([1955] 1975, I:4) roots the being of things in meaningfulness, we find ourselves asking what is the meaningfulness of programs? There are several 'levels' at which programs can meaningfully be said to exhibit programmable behaviour, one level per aspect. The first sees programs from the psychic aspect, as bit patterns, pixels and their manipulation. At the analytical aspect this is seen as data, like numbers, items, colours or text, and primitive operations, like add and subtract. At the formative aspect, the structures and processes of data are important, so the computer might be a database or word processor. At the lingual aspect, the content or signification of these structures and processes are important. For example, a bar chart on screen signifies a set of quantities, with moreless comparisons, whereas five horizontal lines, dotted with ovals that have vertical lines attached, signifies rhythm and melody on a musical stave, which might be played through the computer's speakers. The manipulation, operations and processing all serve the signification activity, as earlier aspects of it.

Thus, the program represents information or knowledge in a way not found in other technologies. This representation role is one reason why the lingual aspect is the most important one.

Programs can represent the meaning of any aspect (the above examples were of the quantitative and aesthetic aspects). Basden (2008a) suggests that the program may be seen as a virtual law side - (a representation of) the law side in which the information in the computer operates. They are usually deemed good programs if their representation is faithful to the laws of the represented aspects; in a hospital monitoring program, faithful representation of a knowledge of biotic laws means its information is processed in biotically appropriate ways. However, in computer games some laws might be modified; for example, the biotic law of death is set aside in many games, in that characters return to life. This way of understanding programs can encourage clarity, direction and responsibility amongst programmers.

TABLE 1: Computer as Dooyeweerdian subject and object.

\begin{tabular}{lll}
\hline Aspect & Subject-functioning & Object-functioning \\
\hline Quantitative-physical & "Computer obeys electro-magneto-optical laws" & Ditto \\
Organic $\dagger$ & - & 'Computer is mouse, keys, VDU that match the user's organs'. \\
Psychic & - & 'Computer displays colour, sound; responds to stimuli from user'. \\
Analytical & - & 'Computer stores, receives and displays distinct data'. \\
Formative & - & 'Computer processes and structures data'. \\
Lingual & - & 'Computer answers my questions'. \\
& & 'Computer tells us where to go'. \\
Later aspects & 'Computer sends emails'.
\end{tabular}

$\dagger$, This stretches the kernel meaning of the biotic aspect from life functions to 'organism', and is argued in Basden (2011b); not everybody agrees. 
What is the Internet? Are our computers 'part of' the Internet (or Cloud), or is the Cloud 'part of' our computer? Dooyeweerd's notion of correlative enkapsis is useful here: just as a forest comprises trees but each tree only fully actualises its potential in a forest, so it is with the Internet and computers.

The functioning of a computer in all aspects (including later ones) depends on two things: to what extent the computer is designed to function well in each, and how its users use it in each, as discussed in the next three sections.

\section{Software libraries, computer languages and $\mathrm{HCl}$ : Encapsulating knowledge of the world}

There are two kinds of programming, in both of which knowledge is represented or encapsulated, to yield an artefact that takes action in meaningful ways - it might be a calculator, a hospital monitoring computer, a word processor, social media like LinkedIn, a music mixer, and so on. The second kind of programming, undertaken by information system (IS) developers and discussed in the next section, encapsulates knowledge of specific types of meaningful reality so that humans can use them. The first kind, undertaken by computer scientists, encapsulates generic knowledge of the way the world works, as software libraries made available to be employed by IS developers. 'Generic knowledge of the way the world works' is, under Dooyeweerd, knowledge of the laws of aspects, so it is useful to classify software libraries according to aspect. In Stafleu's terminology, this projects the lingual aspect of representation onto each aspect in turn.

Originally, the main kind of meaningful reality that computers were tailored to handle, and for which libraries were created, was quantitative (from which 'computers' were named). In the 1970s, it became clear that they could also handle entities and properties, which cannot be reduced to numbers. In the 1980s text, graphics and sounds started to be handled, then animation and music. Video followed in the 1990s. In parallel with these, techniques developed for handling spatial and kinematic meaning, as in SatNavs. The 2000s saw the tailoring of computers to handle social content. Dooyeweerd's notion of progressively opening up aspects accounts for this history surprisingly well.
The software libraries encapsulate three things for the aspect: information structures and processes (algorithms) meaningful in each aspect, 'languages' in which to represent our knowledge of these, and user interface facilities by which users will interact with them (e.g. bar charts, musical staves). For example, quantities may be appropriately expressed by digits and bar charts, but not musical staves. Table 2 gives examples of things and operations meaningful in some of the aspects, from which information structures and processes are constructed; Basden (2008a) discusses these, with languages and so forth, for all aspects.

The mandate of computer science and engineering may thus be seen as creating software libraries (information structures, algorithms, languages and interface constructs) that encapsulate or express our best understanding of each aspect. (This is a second reason why it is appropriate to see computers as qualified by the lingual aspect.) Since aspects are irreducible to each other in their meaning and laws, no software library can adequately stand in for others and, where this is attempted, development becomes difficult, errors abound and costs soar. For example, trying to treat complex spatial objects in terms of their (quantitative) coordinates can lead to errors such as the inability of coping with shapes with holes. However, a Dooyeweerdian understanding of aspectual inter-dependency shows how libraries and so forth should relate to each other, and interaspect analogy can guide the design of user-interactions.

Unfortunately, good libraries and so forth have yet to be developed for all aspects, so IS developers must resort to expressing the laws of one aspect in terms of others. Though this is possible because of inter-aspect analogy (cf. Dooyeweerd ([1955] 1975, I:59), research must continue to develop a full set.

\section{Development of information systems for use in the world}

The second kind of programming builds applications for use in human life, using the libraries created above. Methodology for this has developed since the 1960s, when it was conflated with the first kind. After it was differentiated from the first in the 1970s, methods were devised that were driven by deterministic views of economics and control (cf. naturefreedom ground-motive). In the 1980s the human element

TABLE 2: Meaningful things and operations represented in computers.

\begin{tabular}{lll}
\hline Aspect & Meaningful things & Meaningful operations \\
\hline $\begin{array}{l}\text { Quantitative } \\
\text { Spatial }\end{array}$ & Numbers, more, less & Arithmetic and statistical operations \\
& $\begin{array}{l}\text { Areas, planes, shapes, directions } \\
\text { inside, outside, left, right, near, far }\end{array}$ & Rotate, clip, merge, occlude, surround \\
Kinematic & Path, speed, animation; fast, slow & Find path, follow path, render animation \\
Psychic & $\begin{array}{l}\text { Colour (hue, saturation, brightness); sound (volume, pitch, timbre), } \\
\text { octave }\end{array}$ & $\begin{array}{l}\text { Darken, shade (e.g. antique), increase contrast, detect edges, create } \\
\text { waveform, play it }\end{array}$ \\
Analytical & Concepts, inequalities, truth values & Create, delete, deduce \\
Formative & Relationships, structures, instructions & Relate, build, modify, execute \\
Lingual & Words, sentences, diagrams, headings, emphasis, cross-references, & Write, emphasise, rewrite, spell-check, add to vocabulary \\
Economic & vocabularies, glossaries, thesauri & Double-entry bookkeeping operations, transaction processing, materials \\
\end{tabular}


was recognised in, for example, 'soft systems methodology' (Checkland 1981), and during the 1990s the importance of social structures was recognised. During the 2000s, the kinematic, aesthetic and juridical aspects of development were recognised in Agile methods, and ethics became recognised.

An information system (IS) is an application (technical software artefact designed for certain purposes) in its human or organisational context (such as rules for its use). Developing these is multi-aspectual human functioning, and Dooyeweerd's aspects, because of their innate normativity, lend themselves to guiding development.

Once we begin to separate out norms and laws, we find each aspect is meaningful in several different ways, and that at least four different human activities are involved: eliciting knowledge of the domain of application from experts, anticipating use by getting to know what potential users need and how they are likely to use it (often called 'user requirements analysis'), creating the IS by design, knowledge representation and testing, and orchestrating the entire development project ('project management') (Basden 2008a). Table 3 shows examples of these for three aspects.

Basden (2008a) discusses all aspects more fully.

Aspects fulfil different purposes. In knowledge elicitation, they are directed to existing knowledge whilst in anticipating use, they are directed to future possibility, and in the other two they are directed to present behaviour. In each of the four activities a different aspect is of primary importance. In programming, the lingual rather than the formative aspect is of primary importance because programming is an activity primarily of writing and representation. The quality of IS development tends to increase when all aspects function well. This idea was developed into an international master's course on 'Key Issues in Information Systems Development', which proved to be remarkably popular with the students (Basden 2007).

The benefit of referring to Dooyeweerd's aspects in this way is that it helps to uncover and guide the diversity of reallife IS development, so that no key issue is overlooked, in contrast to many formal methodologies and training courses, which focus on a limited range of aspects.

\section{Usage of ICT in its diversity}

From this point of view the computer artefact is in use. It really comes into its own because it was intended for use. Up to the 1970s the focus when considering use was on analytical correctness of calculations, and on functionality. The 1980s saw interest in ease of use, and the 1990s also in benefits such as 'productivity' or 'effectiveness'. Home computing and gaming, where benefits were more varied, began in the 1980s and flourished in the 1990s. The 1990s saw increasing informational use in the World Wide Web and social use via email. This developed into social networking in the 2000s. Meanwhile, e-commerce and e-government were becoming fashionable. Today sees an increase in individual mobile use. Each kind of use expresses a different meaningfulness, which, of course, can be addressed via Dooyeweerd's aspects.

Issues for analysis and research in this area include the kinds of thing they are used for, ease of use and usefulness, benefits and detrimental impact, unexpected and indirect impacts, learning to use, how the shape of the technology changes people's ways of working and living, and so on. Ethical issues are obviously important. Impacts from the use of ICT are on the user, colleagues, organisations, society and world, and they are of great variety. Some are hidden. Dooyeweerd's suite of aspects lends itself well to analysing and researching use because it enables us to understand and tease out variety and also to expose that which is hidden (Strijbos \& Basden 2006; Winfield \& Basden 2006).

A computer in use might be seen as having both qualifying and leading aspects. The qualifying aspect does not vary with application but expresses what all computers do vis-à-vis the user's interaction with it, and this is primarily lingual because the user interacts by means of symbols that carry meaning. The leading aspect is that which is most meaningful to the specific application of the computer, which was usually set during IS development. For example, LinkedIn is led by the social aspect, a translator program is led (as well as qualified) by the lingual and a computer program embedded in hospital monitoring equipment is led by the aspect of health care (ethical and/ or biotic). Occasionally, users find uses that had not been designed for. This taxes traditional understandings, but Dooyeweerd's discussion of the antique shawl being used as a wall hanging ([1955] 1975, III:146) might help us to understand this.

However, restricting interest to two aspects does not do justice to the richness of ICT usage. Basden (2008a) shows that all Dooyeweerd's aspects are important to understanding the usage of ICT. Doing this revealed something else as well, which those in the field had not explored.

TABLE 3: Example of aspects of four activities in IS development.

\begin{tabular}{|c|c|c|c|c|}
\hline Aspect & Knowledge elicitation & Anticipating use & Creating the IS & Orchestrating project \\
\hline Analytic & Clear concepts of domain & $\begin{array}{l}\text { Clear understanding of what users need } \\
\text { (needs vs. wants) }\end{array}$ & Clearly written programs & Clear objectives \\
\hline Formative & Structuring domain knowledge & Structuring user needs & Designing the program structure & Planning; achieving objectives \\
\hline Lingual & $\begin{array}{l}\text { Interviews with domain experts and } \\
\text { reading around the topic }\end{array}$ & Interviews with potential users & Programming, documentation & Team communications \\
\hline Social & $\begin{array}{l}\text { Relating to domain experts, so they } \\
\text { provide tacit knowledge }\end{array}$ & Relating to potential users & Team working & Leadership \\
\hline Ethical & 'Loving' domain knowledge & Patience with users who change their minds & Incorporating flexibility & Generous, self-giving leadership \\
\hline
\end{tabular}


Ease of use and usefulness have traditionally been studied in completely separate fields (human - computer interaction, and information systems). Despite Davis (1989) recognising both in a seminal paper in 1989, there has been little real dialogue between the two fields. Basden's (2008a) multiaspectual analysis showed not only that ease of use and usefulness both involve all aspects, which provides a basis for integration, but also that there is a third issue distinct from both: engagement with meaningful content (i.e. information), which neither field can properly cover (Breems \& Basden 2014; Joneidy \& Basden 2013). Analysing the aspects of engaging with content helps address issues the community finds challenging, such as computer procrastination (Breems \& Basden 2014), email scams, virtual reality and gaming. Just as in IS development there are four multi-aspectual functionings, in ICT use there are at least three.

Dooyeweerd can make a major contribution to the study of ICT usage. The inherent everyday normativity of his aspects adds a practical edge to this approach which opens up fruitful new avenues not only in research and teaching but also in practice. Ahmad \& Basden (2013) use Dooyeweerd to emphasise the importance of, and suggest a way to study, 'down to earth' issues in ICT use. This view has been made the central thrust in an undergraduate course on 'Rich Media' (Basden \& Whatley 2012, Lecture notes).

\section{Impact of ICT on the world, and vice versa}

When millions of individuals use ICT in a certain way, it affects society and the world, and this has been the topic of endless discussion in IS circles, including hopes in the 1970s for increased leisure time and freeing workers from drudgery, through fears that computer games of the 1980s would de-socialise youths, hopes for global information exchange in the 1990s, concerns about technology dependence, privacy and security in the 2000s, and about the impact of social networking software today.

Repeatedly, ICT's promises to humanity have been broken: the 'paperless office' consumes more paper, productivityoriented systems reduce profits, time-saving email consumes more time, social networking software makes people more lonely and self-centred, e-government systems disenfranchise people, and so on. Such conundrums call for explanation.

Research has been governed by paradigms of technological determinism (TD), social construction of technology, which reacted against TD, and social shaping of technology, which tried to combine them but criticised both for ignoring social structures of power. The characteristics of these are well explained by the poles of the nature-freedom groundmotive and Dooyeweerd suggests attempts to combine them ultimately fail. None of them really addresses the problems above.

Instead, Dooyeweerd opens the way to a more fruitful view, as expounded in Schuurman (1980), which sees the development of technology as a whole as led by aspectual norms, and suggests that technology should be led not by its own norms but by the norms of all other aspects. Strijbos \& Basden (2006) propose an 'Integrative Vision for Technology' and Krishnan-Harihara \& Basden (2010) explore Goudzwaard's (1984) notion of idolatry to explain failures in e-government.

In parallel with this, Giddens's (1993) work has been applied to technology, especially his structurated relationship between agents and society, of norms, power and meaning. What Giddens actually says about these echoes Dooyeweerd's juridical, ethical and pistic aspects. Dooyeweerd offers two ways to enrich Giddens's approach. One is an understanding of how these three 'societal' aspects echo and depend on individual and organisational aspects. The other is correlative enkapsis, which helps us understand the circular structurational relationship itself. These insights, coupled with a Dooyweerdian understanding from other fields, of computer use as lawsubject-object relationships in all aspects, and Internet as enkapsis, might open new doors to understanding how the attitudes and actions of agents have an impact on society and are in turn affected by society.

Within this field, ICT tends to be lumped together with all technology, and thus viewed as qualified by the formative aspect. This is because the view does not penetrate to actual usage and development as covered by the first four fields. That ICT in society is qualified by the lingual aspect is supported by the growing interest in 'technology as text' (Grint \& Woolgar 1997).

\section{Scientific research appropriate to ICT and IS}

Research is underway in each of the above five areas. None of them are natural sciences. Though initially the methods applied were those of corroboration of hypothesis statements (which is how Stafleu characterises science; see later), it became clear from the 1980s onwards that these are inappropriate.

Research in the first field is partly philosophical. The second field employs design science, the main method of which is to encapsulate, in artefacts, laws that work. For example, in order to develop a software library that is appropriate to the economic aspect requires designing this library from a conceptual understanding of its laws, testing it in a wide variety of situations and refining it accordingly. The library may then be said to encapsulate an understanding (a 'theory') of the laws of that aspect, though in working form rather than in the form of statements. Research in IS development and use is interpretive or hermeneutic in nature. This seeks insight about situations that are too complex to express in hypothesis statements, and involves the hermeneutic circle instead of corroboration (Klein \& Myers 1999). Research into the relationship between ICT and society can be interpretive but is often critical-social in nature, the aim of which is to critique and transform the status quo and create a better world (Myers \& Klein 2011). 
Stafleu's view might fit the natural sciences, but Dooyeweerd's ([1955] 1975, I) transcendental critique of theoretical thought adroitly fits all of these varied kinds. Dooyeweerd's critique recognises three elements:

- In research, data are obtained by abstracting aspects of the world that are important to the researcher (a 'Gegenstand" relation). The choice of aspect(s) is pretheoretical. Whilst hypothesis-corroboration research limits itself to one aspect, interpretive and other types of research must be open to multiple aspects.

- Each aspect defines a different rationality. Since there is no overarching rationality, the researcher takes responsibility for orchestrating them to generate new findings from the data that might make a contribution to humanity's body of knowledge of the field. This responsibility is pre-theoretical. Whilst hypothesiscorroboration research often involves two rationalities, design research requires tacit combination of many, and interpretive and critical-social research requires the explicit consideration of many.

- Such potential contributions are discussed and refined. This discourse is 'supra-individual' Dooyeweerd [1955] 1975, I:59), involving critical self-reflection, which ultimately requires reference to an Origin of Meaning. What the research community treats as its Origin of Meaning is governed by prevailing religious (pre-theoretical) ground-motives. Both critical-social and philosophical research of the first and fifth fields involve critical self-reflection ('What is human?') and Dooyeweerd's ground-motive of creation-fallredemption offers new insight into the functioning of humans, computers and society.

Dooyeweerd's transcendental critique resonates well with the realities of IS or ICT research, and can advance our understanding of them. Eriksson (2003) argues that Dooyeweerd can overcome an assumed incommensurability between IS research approaches and Basden (2011a) details how they can be fruitfully integrated. It frees Christian thinkers from an antithetical approach to extant research, enabling them to engage with the approaches by affirmation, critique and enrichment (Basden 2008b).

\section{Conclusions}

Stafleu's (2014) views lead him to a valuable first step in understanding artefacts, namely to differentiate broad kinds of artefact on the basis of which aspect the formative functioning of humanity is projected onto. Whilst Stafleu restricts his discussion to the pre-human aspects, my response considers a human aspect, the lingual, which makes possible information and communication technology and systems. We have shown how it is possible and fruitful to go further, by employing aspects and other portions of Dooyeweerd's philosophy to understand the nature of computers as artefacts in five different ways:

- Computers are subjects and objects in aspectual functioning, programs are virtual law sides.
- Software libraries, computer languages and HCI are the realisation of lingual possibility of representing aspectual laws.

- IS development is four multi-aspectual human functionings.

- Usage of ICT is three multi-aspectual functionings.

- ICT in society is correlative enkapsis, directed by norms of all other aspects.

A Dooyeweerdian understanding in each of these can offer fresh ways of understanding (new paradigms) in each, which spawns new insights and opens up new opportunities in each area. How this can engage with extant thought in each field has been briefly discussed.

In addition, this article has shown how Dooyeweerd's transcendental critique very nicely accounts for research in these areas, beyond the hypothesis-corroborating approach that Stafleu assumes. Design, interpretive and criticalsocial sciences must be taken into account alongside natural sciences.

\section{What Dooyeweerd can offer}

The discussion above has demonstrated the fruitfulness of Dooyeweerd's philosophy when applied to a discipline such as ICT and IS. The following collects together portions of Dooyeweerd's thought found most useful; Table 4 summarises them.

Dooyeweerd's transcendental critique of theoretical thought is particularly useful to understanding the way research is carried out in the various fields related to ICT/IS, because it can embrace not only hypothesis-corroboration research found in the natural sciences, but also design research, philosophical research, interpretive research, and criticalsocial research, which are important in the various fields discussed. Dooyeweerd's transcendental critique can do this because it begins with the pre-theoretical attitude and asks what is meaningful, because it does not assume one overarching kind of rationality but relies on human responsibility, and because it recognises that research includes communal discourse that refers to an origin of meaning.

Dooyeweerd's notion of ground-motives is helpful in two areas. Firstly, since ground-motives are origins of meaning in theoretical thought, they can be used in understanding the dialectical fashions in research in each area, and Dooyeweerd's ground-motive of creation-fallredemption can point a way to fruitful integration (Basden 2011a). Secondly, they are helpful in understanding the philosophical conflicts around the artificial intelligence question of whether computers can be like humans, and offering fruitful new ways of approaching the question.

Dooyeweerd's notion of a diverse law side is useful in developing software libraries that encapsulate the laws and structures of the world. Computer programs may be seen 
as an alternative law side by means of which virtual worlds exist and occur.

Dooyeweerd's radically interesting notion of subject and object is useful in AI to show that the AI question in fact conflates two questions. His notion of correlative enkapsis is important for understanding computer-Internet and technology-society relationships.

Finally, Dooyeweerd's aspects are perhaps the most important portion of his thought. Both his suite of aspects and his idea that all things are meaningful and function in all aspects, are used in all areas. They provide different levels at which to understand computers, guidance in developing software libraries that afford realistic laws and structures, a way to ensure that no key issues are overlooked in IS development, a way to understand ICT use, and norms to guide technological development within society. In some of these areas, important new avenues for study have been revealed. Finally, they provide a way to understand the kinds of data researchers seek, the kinds of rationality they employ and the kinds of meaningfulness that drive the community's discourse.

\section{What ICT and IS can offer Dooyeweerdian philosophy}

'It is a matter of life and death for this young philosophy,' remarked Dooyeweerd ([1955] 1975, I:vii), 'that Christian scholars in all fields of science seek to put it to work in their own specialty.' It may be that the application of Dooyeweerd's idea to ICT and IS can feed back and contribute to the development of Dooyeweerd's philosophy.

The application of his idea can provide examples of the application of his philosophy. This can be valuable because much of the application is to the everyday experience of ICT users and developers, not just in IS research. In this role, it can affirm, sharpen up and even challenge some of Dooyeweerd's ideas. For example, a wide range of examples confirm Dooyeweerd's idea of multi-aspectual functioning with intrinsic normativity, and most affirm Dooyeweerd's suite of aspects. However, that both ICT use and IS development involve several multi-aspectual activities intertwined provides interesting material for the development of this notion.

It provides copious material for discussion of the kernel and constellation of the meaning of aspects, in line with Dooyeweerd's ([1955] 1975) contention that:

A more penetrating examination may at any time bring new modal aspects of reality to the light not yet perceived before. And the discovery of new law-spheres will always require a revision and further development of our modal analyses. (p. II:556)

If ICT and IS are seen as part of humanity's opening up of the lingual aspect, then a sensitive understanding of all kinds of ICT use and development can help expand our understanding of that aspect as affording more than just reading, writing, and so forth. As mentioned in the footnote to Table 1, it may be that the biotic aspect can be slightly modified from life functions to organisms. The material might also be useful for clarifying contended understandings of Dooyeweerd's notions of anticipation, retrocipation, dependency and analogy, and Stafleu's (2014) notion of projection.

The approach to ICT and IS outlined here reaffirms Dooyeweerd's emphasis on meaningfulness as the root of being, process and rationality. Aspects are usefully seen as spheres of meaning as well as law-spheres, and ICT and IS can stimulate philosophical discussion of what meaningfulness is, and its relation to law. Dooyeweerd's notion of law side can perhaps be enriched by the suggestion that programs are artificial law sides for virtual worlds, and it may be that ICT opens a way to empirical, not just philosophical, investigation of Dooyeweerd's idea.

That the interaction between user and computer exhibits both subject-subject and subject-object relationships simultaneously might provide material for a deeper philosophical exploration of Dooyeweerd's version of these. The idea of aspects as possibility challenges Dooyeweerd's contention that possibility is of the subject side of temporal reality, and might help us clarify Dooyeweerd's notion of anticipation and retrocipation.

TABLE 4: Importance of Dooyeweerd's ideas.

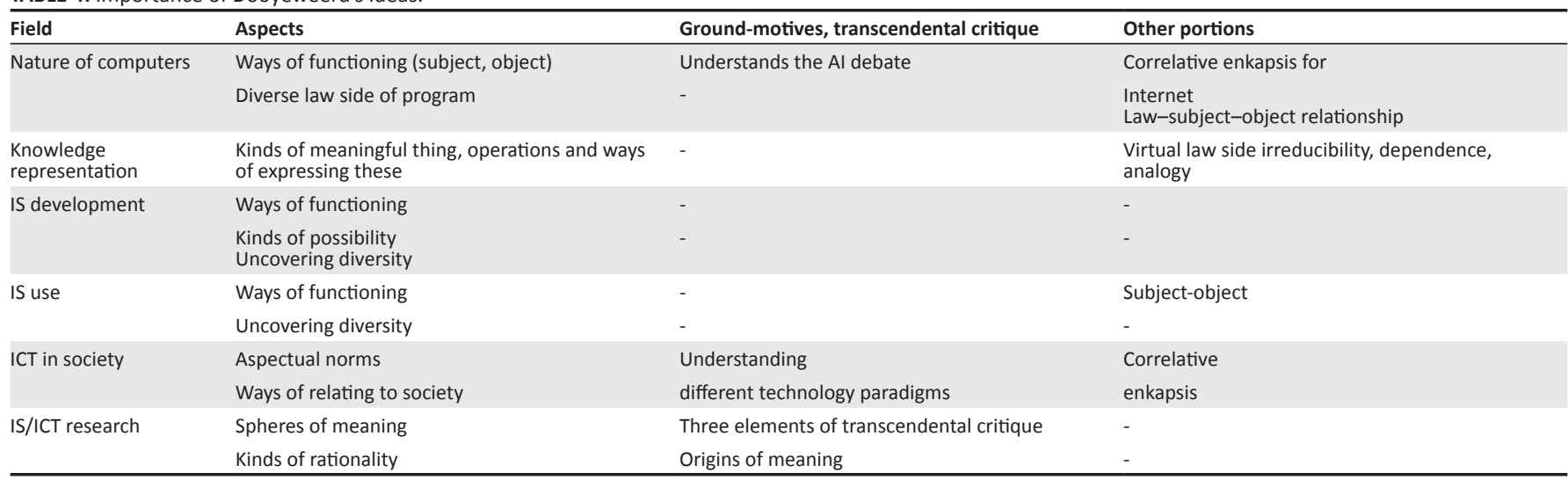


ICT and its use might reveal new kinds of enkaptic relationship in addition to the five Dooyeweerd discussed. It might also reveal new roles for aspects beyond those Dooyeweerd discussed (qualifying, founding, leading and internal leading).

Finally, the usefulness and intuitive usability of aspects in analysis, especially of 'down to earth' issues (Ahmad \& Basden 2013), might contribute to Dooyeweerd's theory of knowledge, especially opening up new avenues of understanding of intuition and pre-theoretical engagement.

\section{Reflection on Stafleu's views}

In the light of this, and the need to introduce Dooyeweerd to people in each field, certain of Stafleu's views are particularly helpful to us whilst others are less so.

Stafleu's explanation of Dooyeweerd's subject-object relationship, and calling the fact side the 'subject and object side', are both clear and helpful. What is particularly helpful is Stafleu's discussion of projection of one aspect on another, when seen as the functioning in one aspect directed to serve purposes in another. Projection expresses a kind of relationship between aspects that Dooyeweerd did not seem to give much attention to. That this is not mere analogy, as Stafleu asserts, is important. This not only helps delineate types of artefact, but also expresses what knowledge representation is doing when laws of various aspects are encapsulated in software libraries. It is a useful idea in thinking about the application of technology, such as for agriculture, counting, and so forth.

Basden (2008a) also recognised this kind of relationship, calling it 'reaching out', and gave examples of writing (lingual functioning) directed towards the topic of writing, or the quantitative aspect directed towards what it is that exhibits amount. Stafleu's (2014) discussion is more detailed than Basden's, but unfortunately Stafleu confuses it with the idea of the founding aspect, and limits it to projection to earlier aspects. He need not do so; the application of technology (whether informational or other) is often towards later aspects, such as the social or aesthetic.

However, his designating aspects as relation frames is not particularly helpful, especially for introducing scholars and practitioners in these fields to Dooyeweerd's ideas. 'Relation frame' speaks too strongly of ways of relating, whilst in most fields of ICT the importance of aspects lies elsewhere, as shown in Table 4. Though it may be argued that the concept behind the label 'relation frames' can include some of these, the label itself misleads, and the old label 'aspects' seems preferable.

Stafleu (2014) rejects Dooyeweerd's view 'that it would be possible to start theoretical thought from something that is not theoretical' and holds instead that ' $t]$ heoretical thought is nothing but thought aided by theories, which in turn depend on artefacts such as statements and concepts'. As a result, he holds a rather narrow view that 'science works with hypothetical statements about laws, trying to corroborate these statements by confronting them with states of affairs considered as facts and by relating them' (Stafleu 2014:3). His view does not express the realities of design, interpretive or critical-social sciences that are important in the ICT fields. Hypothesis corroboration presupposes that hypotheses have already been formulated; Dooyeweerd's first element makes explicit the limitation in Stafleu's view, and so does scientific practice of the past 40 years (e.g. Glaser \& Strauss 1967; Klein \& Myers 1999; Myers \& Klein 2011). Dooyeweerd's view fits research in the above five areas more closely than does Stafleu's. Does Stafleu's limitation arise from his long-term penchant for natural sciences?

Curiously, Stafleu makes no reference to the ground-motives that Dooyeweerd believed lie at the root of all theoretical thought. We have shown how they have been important in at least two of the fields above.

Stafleu focuses on artefacts because Dooyeweerd and Strauss have not sufficiently done so, and he should be applauded for pointing the way. By setting off in the direction he points to, we can use Dooyeweerd's philosophy in ways that even Stafleu does not seem to have appreciated. Exploring kinds of artefact related to the human as well as pre-human aspects, we discover fresh insights that make genuine contributions to the various fields of scholarship and practice.

\section{Acknowledgements Competing interests}

The author declares that he has no financial or personal relationship(s) that may have inappropriately influenced him in writing this article.

\section{References}

Ahmad, H. \& Basden, A., 2013, 'Down-to-earth issues in information system use', Proceedings of the Pacific Area Conference on Information Systems (PACIS), Paper 191.

Basden, A., 2007, Key issues in information systems development: Lecture notes, University of Salford, Salford.

Basden A., 2008a, Philosophical frameworks for understanding information systems, IGI Global, Hershey.

Basden, A., 2008b, 'Engaging with and enriching humanist thought: The case of information systems', Philosophia Reformata 73(2), 132-153.

Basden A., 2011a, 'Enabling a Kleinian integration of interpretivist and critical-social IS research: The contribution of Dooyeweerd's philosophy', European Journal of Information Systems 20, 477-489. http://dx.doi.org/10.1057/ejis.2011.18

Basden, A., 2011b, 'A presentation of Herman Dooyeweerd's aspects of temporal reality', International Journal of Multi-aspectual Practice 1(1), 1-28.

Breems, N. \& Basden, A., 2014, 'Understanding of computers and procrastination: A philosophical approach', Computers in Human Behavior 31, 211-223. http:// dx.doi.org/10.1016/j.chb.2013.10.024

Checkland, P., 1981, Systems thinking, systems practice, Wiley, New York.

Davis, F., 1989, 'Perceived usefulness, perceived ease of use, and user acceptance of information technology', MIS Quarterly 13(3), 319-339. http://dx.doi. org/10.2307/249008

Dooyeweerd, H., [1955] 1975, A new critique of theoretical thought, vols. I-IV, Paideia Press, Jordan Station, Ontario.

Eriksson, D.M., 2003, 'Identification of normative sources for systems thinking: Inquiry into religious ground-motives for systems thinking paradigms', Journal of Systems Research and Behavioral Science 20(6), 475-487. http://dx.doi.org/10.1002/ sres.579

Giddens, A., 1993, New rules of sociological method, Polity Press, Cambridge.

Glaser, B.G. \& Strauss, A.L., 1967, The discovery of grounded theory: Strategies for qualitative research, Aldine de Gruyter, New York. 
Goudzwaard, B., 1984, Idols of our time, Inter-Varsity Press, Downers Grove. Grint, K. \& Woolgar, S., 1997, The machine at work, Polity Press, Cambridge.

Joneidy, S. \& Basden, A., 2013, 'Five paradigms of information system use: Affirmation, critique and enrichment', UKAIS-12, Oxford.

Klein, H.K. \& Myers, M.D., 1999, 'A set of principles for conducting and evaluating interpretive field studies in information systems', MIS Quarterly 23(1), 67-93. http://dx.doi.org/10.2307/249410

Krishnan-Harihara, S. \& Basden, A., 2010, 'Is idolatry a suitable tool to teste-government?', in R. Goede, L. Grobler \& D.E. Haftor (eds.), Interdisciplinary Research for Practices of Social Change. Proceedings, 16th Annual Working Conference of the Centre for Philosophy, Technology and Social Systems (CPTS), Maarssen, Netherlands. CPTS, Maarssen / BZ Repro, Haaksbergen, Netherlands, 13-16 April 2010, pp. 107-125.
Myers, M.D. \& Klein, H.K., 2011, 'A set of principles for conducting critical research in information systems', MIS Quarterly 35(1), 17-36.

Schuurman, E., 1980, Technology and the future: A philosophical challenge, Wedge Publishing, Toronto.

Stafleu, M.D., 2014, 'Nuances in the Philosophy of the Cosmonomic Idea' Koers - Bulletin for Christian Scholar

Strijbos, S. \& Basden, A. (eds.), 2006, In search of an integrative vision of technology: Interdisciplinary studies in information systems, Springer, New York. http://dx.doi. Interdisciplinary studies in infor
org $/ 10.1007 / 0-387-32162-4$

Winfield, M.J. \& Basden, A., 2006, 'Elicitation of highly interdisciplinary knowledge', in S. Strijbos \& A. Basden (eds.), In search of an integrated vision for technology: Interdisciplinary studies in information systems, pp. 63-78, Springer, New York http://dx.doi.org/10.1007/0-387-32162-4 